\title{
Diabetes mellitus, metformin and head and neck cancer
}

\section{de Oliveira Figueiredo, Rejane Augusta}

2016-10

de Oliveira Figueiredo , R A , Weiderpass , E , Tajara , E H , Strom , P , Carvalho , A L , de Carvalho , M B , Kanda , J L, Moyses, R A \& Wunsch-Filho , V 2016 , ' Diabetes mellitus, metformin and head and neck cancer ' , Oral Oncology , vol. 61 , pp. 47-54 . https://doi.org/10.1016/j.oraloncology.2

http://hdl.handle.net/10138/228224

https://doi.org/10.1016/j.oraloncology.2016.08.006

publishedVersion

Downloaded from Helda, University of Helsinki institutional repository.

This is an electronic reprint of the original article.

This reprint may differ from the original in pagination and typographic detail.

Please cite the original version. 


\title{
Diabetes mellitus, metformin and head and neck cancer
}

\author{
Rejane Augusta de Oliveira Figueiredo ${ }^{\mathrm{a}, \mathrm{b}, *}$, Elisabete Weiderpass ${ }^{\mathrm{c}, \mathrm{d}, \mathrm{e}, \mathrm{f}}$, Eloiza Helena Tajara ${ }^{\mathrm{g}}$, Peter Ström ${ }^{\mathrm{b}}$, \\ André Lopes Carvalho ${ }^{\mathrm{h}}$, Marcos Brasilino de Carvalho ${ }^{\mathrm{i}}$, Jossi Ledo Kanda ${ }^{\mathrm{j}}$, Raquel Ajub Moyses ${ }^{\mathrm{k}}$, \\ Victor Wünsch-Filho ${ }^{\text {a }}$
}

\author{
${ }^{a}$ Faculdade de Saude Publica, Departamento de Epidemiologia, Universidade de Sao Paulo, Av. Dr Arnaldo, 715, 01246-904 Sao Paulo, SP, Brazil \\ ${ }^{\mathrm{b}}$ Department of Medical Epidemiology and Biostatistics, Karolinska Institutet, Nobels väg 12, SE-171 77 Stockholm, Sweden \\ ${ }^{\mathrm{c}}$ Department of Medical Epidemiology and Biostatistics, Karolinska Institutet, PO Box 281, SE-171 77 Stockholm, Sweden \\ ${ }^{\mathrm{d}}$ Department of Community Medicine, Faculty of Health Sciences, University of Tromsø, The Arctic University of Norway, Tromsø N-9037, Norway \\ e Department of Research, Cancer Registry of Norway, PB 5313 Majorstuen, 0304 Oslo, Norway \\ ${ }^{\mathrm{f}}$ Genetic Epidemiology Group, Folkhälsan Research Center, PB 63, FI-00014 University of Helsinki, Helsinki, Finland \\ ${ }^{\mathrm{g}}$ Faculdade de Medicina de São José do Rio Preto, Departamento de Biologia Molecular, Av Brigadeiro Faria Lima n 5416, 15090000 São José do Rio Preto, SP, Brazil \\ ${ }^{\mathrm{h}}$ Fundação PIO XII, Hospital de Câncer de Barretos, Av. Antenor Duarte Villela, 1331, 14784400 Barretos, SP, Brazil \\ ${ }^{i}$ Hospital Heliópolis, Rua Cônego Xavier, 276, 04231-030 Sao Paulo, SP, Brazil \\ ${ }^{\mathrm{j}}$ Faculdade de Medicina do ABC, Hospital de Ensino, Rua Silva Jardim, 470, 09715-090 Sao Bernardo do Campo, SP, Brazil \\ ${ }^{\mathrm{k}}$ Cirurgia de Cabeça e Pescoço (LIM 28), Faculdade de Medicina, Universidade de São Paulo, Av. Dr. Enéas de Carvalho Aguiar, 255, $8^{\circ}$ andar, 05403900 São Paulo, SP, Brazil
}

\section{A R T I C L E I N F O}

\section{Article history:}

Received 11 April 2016

Received in revised form 17 June 2016

Accepted 20 August 2016

Available online 26 August 2016

\section{Keywords:}

Head and neck cancer

Diabetes mellitus

Metformin

Case-control studies

\section{S U M M A R Y}

Introduction: Diabetes mellitus (DM (Diabetes Mellitus)) is directly associated with some cancers. However, studies on the association between diabetes mellitus and head and neck cancer (HNC (Head and Neck Cancer)) have rendered controversial results. The objective of this study was to evaluate the association between DM and HNC, as well as the impact of metformin use on the risk of HNC.

Material and methods: This case-control study was conducted within the framework of the Brazilian Head and Neck Genome Project in 2011-2014. The study included 1021 HNC cases with histologically confirmed squamous cell carcinoma of the head and neck admitted to five large hospitals in São Paulo state. A total of 1063 controls were selected in the same hospitals. Odds ratios (OR) and 95\% confidence intervals $(\mathrm{CI})$ were estimated using unconditional logistic regression.

Results: Diabetic participants had a decreased risk of HNC (OR $=0.68$; 95\% CI: 0.49-0.95) than nondiabetic participants, and this risk was further decreased among diabetic metformin users $(\mathrm{OR}=0.54$; 95\% CI: 0.29-0.99). Diabetic metformin users that were current smokers (OR =0.13; 95\% CI: $0.04-0.44$ ) or had an alcohol consumption of $>40 \mathrm{~g} /$ day $(\mathrm{OR}=0.31 ; 95 \% \mathrm{CI}: 0.11-0.88)$ had lower risk of HNC than equivalent non-diabetic participants.

Conclusion: The risk of HNC was decreased among diabetic participants; metformin use may at least partially explain this inverse association.

(c) 2016 Elsevier Ltd. All rights reserved.

\section{Introduction}

Head and neck cancer (HNC) includes tumours of the oral cavity, oropharynx, hypopharynx, and larynx. Nasopharyngeal cancer is also a HNC sub-site but is usually considered a separate disease

* Corresponding author at: Faculdade de Saude Publica, Departamento de Epidemiologia, Universidade de Sao Paulo, Av. Dr Arnaldo, 715, 01246-904 Sao Paulo, SP, Brazil.

E-mail addresses: rejane.figueiredo@usp.br (R.A.O Figueiredo), elisabete. weiderpass.vainio@ki.se (E. Weiderpass), etajara@hotmail.com (E.H. Tajara), peter. strom@ki.se (P. Ström), alopescarvalho@uol.com.br (A.L. Carvalho), brasilino. heliopolis@gmail.com (M.B. de Carvalho), jossikanda@uol.com.br (J.L. Kanda), ramccp@gmail.com (R.A. Moyses),wunsch@usp.br (V. Wünsch-Filho). with a distinct aetiology and particular characteristics [1]. Approximately 600,000 cases of HNC are diagnosed each year, and HNC accounts for $4 \%$ of cancer mortality worldwide [2]. More than $90 \%$ of HNC are squamous cell carcinoma [3]. The main risk factors associated with HNC are smoking and alcohol consumption, and the interaction between these factors can increase the risk of HNC [4]. Other risk factors include poor oral health, diet, genetic factors, low body mass index (BMI), and occupational factors [5-8].

The association between diabetes mellitus (DM) and the increased risk of certain cancers, such as liver, pancreatic, colon, kidney, bladder, endometrial, and breast cancer, is well established [9-11], while the risk of prostate cancer is decreased among diabetic patients $[11,12]$. Although some studies with DM has also 
Table 1

Description of excluded and included cases and controls.

\begin{tabular}{ll}
\hline Description & Subjects \\
\hline Cases included & 1021 \\
Cases excluded & 270 \\
Missing anatomical location of tumor & 126 \\
Missing morphology information & 50 \\
Cancer diagnosis not confirmed & 34 \\
Cancer at other sites (not HNC) & 21 \\
Others histology (not SCC) & 12 \\
Cancer in situ & 9 \\
Synchronous cancers & 7 \\
Previous cancer treatment & 4 \\
Cancers with previous HNC treatment & 3 \\
Repeat cases & 3 \\
Missing information on diabetes mellitus & 1 \\
Total cases & 1291 \\
Controls included & 1063 \\
Controls excluded & 52 \\
Did not meet inclusion criteria & 36 \\
With cancer diagnosis & 13 \\
Repeated controls & 3 \\
Total controls & 1115 \\
\hline
\end{tabular}

HNC: head and neck cancer; SCC: squamous cell carcinoma.

been associated with HNC, these results are still controversial. In some studies, diabetic patients had an increased risk of cancer at some HNC sub-sites [10,13-15], while in other studies this risk was decreased $[9,16]$.

One possible explanation for inverse association between DM and some kinds of cancers is metformin use among diabetic patients. Metformin is a medication used to control Type 2 DM and can inhibit cell proliferation, which has been inversely associated with cancer risk $[11,17]$. It has been shown that metformin users have a reduced risk of colorectal, liver, lung, and prostate cancer [18-20]. Studies on the association between DM and the risk of HNC that take into account metformin use have also reported conflicting results. A Taiwanese study reported a decreased risk of HNC among metformin users (adjusted hazard ratio $=0.66 ; 95 \%$ confidence interval $[\mathrm{CI}]$ 0.55-0.79) [21], while another study in the United Kingdom reported no association [22].

The objective of this study was to evaluate the association between DM and HNC, as well as the impact of metformin use on the risk of HNC.

\section{Material and methods}

This case-control study was conducted within the framework of the Brazilian Head and Neck Genome Project (GENCAPO) from December 2011 to November 2014. The study recruited 1291 HNC cases admitted to three general hospitals and two cancer hospitals in Sao Paulo state, Brazil. All HNC cases had histologically confirmed squamous cell carcinoma of the head and neck, and the International Classification of Diseases, 10th Revision [23] was used to classify these cancers into five sub-sites [24]: oral cavity, oropharynx, hypopharynx, larynx, and oral-oropharynxhypopharynx not specified.

A total of 1115 controls were selected from the same hospitals as the HNC cases: in the general hospitals we recruited hospital controls who were individuals admitted with diseases other than cancer (for example, diseases related to skin, eyes, ears, genitourinary tract, circulatory disorders, nervous system disorders and others); visitor controls were recruited in the cancer hospitals, excluding visitors of HNC patients, since they could have similar habits to the HNC patients.

After exclusions, the final study sample comprised 1021 cases and 1063 controls (Table 1). Controls were frequency-matched to
HNC cases by sex and age (in 5-year groups). This study was approved by the institutional ethical review boards of all hospitals, and all participants gave written informed consent.

\section{Data collection}

Participants were interviewed using a standardised questionnaire to collect information on socio-demographic, socioeconomic, and lifestyle factors, as well as family history of cancer. Authors extracted information on age, sex, education, BMI (based on height and weight 2 years before the interview), DM, tobacco consumption, and alcohol consumption from the questionnaire.

Blood samples were also collected from cases and controls, stored in tubes containing EDTA at $-70^{\circ} \mathrm{C}$, and used for glycated haemoglobin tests (A1C). A1C provides an average assessment of glucose control for the previous 60-90 days without the need for fasting. A1C was performed using $1 \mathrm{ml}$ of blood at a laboratory certified by the National Glycohemoglobin Standardization Program and was considered positive for diabetes when values were above $6.5 \%[25]$.

The final DM variable was constructed by combining information from three sources in order to ensure a better characterisation of the main explanatory variable and avoid underestimating the prevalence of DM. Thus, participants who reported they were diabetic at interview, or had a diagnosis of DM in medical records, or had a positive A1C result were categorised as diabetic (Table 2). Patients with self-reported DM were categorised as diabetic even if A1C values were below 6.5\% (controlled DM). Diabetic participants were then further categorised as metformin users and nonusers. Information about metformin use was taken from medical records.

Tobacco consumption was assessed in pack-years, calculated by multiplying the average number of packs of cigarettes smoked in 1 day by the number of years the participant smoked. One cigarette, one pipe and one cigar are equivalent to $1 \mathrm{~g}, 3.5 \mathrm{~g}$ and $4 \mathrm{~g}$ of tobacco, respectively. Analyses were performed for both smoking status and pack-years of tobacco consumption.

Alcohol consumption was assessed in $\mathrm{g} /$ day. One litter of different alcoholic beverages was converted to $5 \%, 12 \%$, and $40 \%$ of alcohol for beer, wine, and spirits, respectively. Consumption was then converted to grams of alcohol (one litter is equivalent to $798 \mathrm{~g}$ of alcohol) and the daily average alcohol intake during the consumption period was calculated. Analyses were performed for both drinking status and g/day of alcohol consumption.

\section{Statistical analysis}

Odds ratios (OR) and 95\% CI were estimated using unconditional logistic regression. Analyses comparing participants with and without DM were adjusted for sex, age, education, BMI (in $\mathrm{kg} / \mathrm{m}^{2}$ ), tobacco consumption, and alcohol consumption. The models were also adjusted for hospital of recruitment (centre), since heterogeneity was detected by the likelihood ratio-test.

In metformin analyses, diabetic metformin users and non-users were compared with those without DM. However, these analyses did not include controls who were visitors in cancer hospitals. Indeed, as they were not patients they did not have medical records available in which to verify metformin use. Consequently, metformin analyses were not adjusted for centre.

Analyses were stratified by sex, HNC sub-site, smoking status, drinking status, tobacco consumption (non-smokers, $>0-40,>40$ pack-years) and alcohol consumption (non-drinkers, $>0-40$, $>40 \mathrm{~g}$ /day).

Missing data were found for the following variables: education (18 cases and two controls), BMI (86 cases and five controls), alcohol consumption ( 50 cases and 20 controls), and tobacco consump- 
tion (seven cases and six controls). Multiple imputation with the PROC MI procedure in version 9.4 of SAS statistical software (SAS Institute, Inc., Cary, North Carolina) was applied in order to include participants with missing data in the analyses. Estimated power for the study was $86.8 \%$. For analysis using metformin information, calculated power was $77.1 \%$. All statistical analyses were conducted using SAS version 9.4 statistical software and a 5\% statistical significance level was adopted.

\section{Results}

Among the 1021 cases and 1063 controls, a higher percentage of current-smokers were observed in cases $(68.0 \%)$ compared to controls (16.3\%). Of cases, 53.6\% were current-drinkers compared with $43.5 \%$ of controls. There were 359 participants with DM, 150
(14.7\%) cases and 209 (19.7\%) controls. A large percentage (18.7\%) of diabetic participants was identified through A1C only.

DM was inversely associated with HNC in both males and females and in all HNC sub-sites (Table 3 ). However, the risk reduction was statistically significant only in males $(\mathrm{OR}=0.68 ; 95 \% \mathrm{CI}$ : $0.47-0.99)$ and in pharyngeal cancer $(\mathrm{OR}=0.43$; $95 \% \mathrm{CI}: 0.27-$ $0.68)$. The decreased risk of HNC associated with DM was most remarkable among heavy smokers ( $>40$ pack-years) and heavy drinkers (>40 g/day) (Table 4 ).

In analyses considering use of metformin were included 1021 cases and 587 hospital controls, only those in which it was possible to confirm or not the use of metformin. So visitor controls who did not have metformin information were excluded from the analysis. Metformin use among diabetic participants was associated with a decreased risk of HNC. A negative association was also observed in patients with pharyngeal and laryngeal cancer (Table 5), as well as

Table 2

Selected characteristics of the study sample by case/control status.

\begin{tabular}{|c|c|c|c|c|c|}
\hline & & \multicolumn{2}{|l|}{ Cases } & \multicolumn{2}{|c|}{ Controls } \\
\hline & & $\mathrm{n}$ & $\%$ & $\mathrm{n}$ & $\%$ \\
\hline Sex & $\begin{array}{l}\text { Male } \\
\text { Female }\end{array}$ & $\begin{array}{l}884 \\
137\end{array}$ & $\begin{array}{l}86.6 \% \\
13.4 \%\end{array}$ & $\begin{array}{l}693 \\
370\end{array}$ & $\begin{array}{l}65.2 \% \\
34.8 \%\end{array}$ \\
\hline Education & $\begin{array}{l}\text { No formal education } \\
\text { Incomplete junior high school } \\
\text { Junior high school } \\
\text { High school graduate } \\
\text { College graduate }\end{array}$ & $\begin{array}{l}136 \\
581 \\
137 \\
119 \\
30\end{array}$ & $\begin{array}{l}13.6 \% \\
57.9 \% \\
13.7 \% \\
11.9 \% \\
3.0 \%\end{array}$ & $\begin{array}{l}74 \\
473 \\
162 \\
239 \\
113\end{array}$ & $\begin{array}{l}7.0 \% \\
44.6 \% \\
15.3 \% \\
22.5 \% \\
10.7 \%\end{array}$ \\
\hline BMI & $\begin{array}{l}<18.5 \\
18.5<25 \\
25<30 \\
\geqslant 30\end{array}$ & $\begin{array}{l}48 \\
536 \\
252 \\
99\end{array}$ & $\begin{array}{l}5.1 \% \\
57.3 \% \\
27.0 \% \\
10.6 \%\end{array}$ & $\begin{array}{l}25 \\
379 \\
375 \\
266\end{array}$ & $\begin{array}{l}2.4 \% \\
36.3 \% \\
35.9 \% \\
25.5 \%\end{array}$ \\
\hline Smoking status & $\begin{array}{l}\text { Non-smoker } \\
\text { Former smoker } \\
\text { Current smoker }\end{array}$ & $\begin{array}{l}76 \\
249 \\
690\end{array}$ & $\begin{array}{l}7.5 \% \\
24.5 \% \\
68.0 \%\end{array}$ & $\begin{array}{l}525 \\
360 \\
172\end{array}$ & $\begin{array}{l}49.7 \% \\
34.1 \% \\
16.3 \%\end{array}$ \\
\hline Tobacco consumption (pack-years) & $\begin{array}{l}\text { Non-smoker } \\
>0-10 \\
11-20 \\
21-30 \\
31-40 \\
41-50 \\
\geqslant 51\end{array}$ & $\begin{array}{l}76 \\
61 \\
65 \\
104 \\
128 \\
135 \\
453\end{array}$ & $\begin{array}{l}7.5 \% \\
6.0 \% \\
6.4 \% \\
10.2 \% \\
12.6 \% \\
13.3 \% \\
44.6 \% \\
\end{array}$ & $\begin{array}{l}525 \\
196 \\
95 \\
63 \\
57 \\
44 \\
106\end{array}$ & $\begin{array}{l}49.7 \% \\
18.5 \% \\
9.0 \% \\
6.0 \% \\
5.4 \% \\
4.2 \% \\
10.0 \%\end{array}$ \\
\hline Alcohol drinking status & $\begin{array}{l}\text { Non-drinker } \\
\text { Former drinker } \\
\text { Current drinker }\end{array}$ & $\begin{array}{l}84 \\
367 \\
520\end{array}$ & $\begin{array}{l}8.7 \% \\
37.8 \% \\
53.6 \%\end{array}$ & $\begin{array}{l}353 \\
236 \\
454\end{array}$ & $\begin{array}{l}33.8 \% \\
22.6 \% \\
43.5 \%\end{array}$ \\
\hline Alcohol consumption (g/day) & $\begin{array}{l}\text { Non-drinker } \\
>0-10 \\
>10-20 \\
>20-30 \\
>30-40 \\
>40-50 \\
>50\end{array}$ & $\begin{array}{l}84 \\
87 \\
52 \\
46 \\
51 \\
46 \\
605\end{array}$ & $\begin{array}{l}8.7 \% \\
9.0 \% \\
5.4 \% \\
4.7 \% \\
5.3 \% \\
4.7 \% \\
62.3 \%\end{array}$ & $\begin{array}{l}353 \\
291 \\
121 \\
63 \\
45 \\
29 \\
141\end{array}$ & $\begin{array}{l}33.8 \% \\
27.9 \% \\
11.6 \% \\
6.0 \% \\
4.3 \% \\
2.8 \% \\
13.5 \%\end{array}$ \\
\hline Type of hospital & $\begin{array}{l}\text { General hospital } \\
\text { Cancer hospital }\end{array}$ & $\begin{array}{l}429 \\
592\end{array}$ & $\begin{array}{l}42.0 \% \\
57.9 \%\end{array}$ & $\begin{array}{l}587 \\
476\end{array}$ & $\begin{array}{l}55.2 \% \\
44.8 \%\end{array}$ \\
\hline Presence of DM & $\begin{array}{l}\text { No } \\
\text { Yes }\end{array}$ & $\begin{array}{l}871 \\
150\end{array}$ & $\begin{array}{l}85.3 \% \\
14.7 \%\end{array}$ & $\begin{array}{l}854 \\
209\end{array}$ & $\begin{array}{l}80.3 \% \\
19.7 \%\end{array}$ \\
\hline \multirow[t]{2}{*}{ HNC sub-site } & $\begin{array}{l}\text { Oral cavity } \\
\text { Oropharynx } \\
\text { Hypopharynx } \\
\text { Larynx } \\
\text { HNC without specification } \\
\text { Multiple localizations }\end{array}$ & $\begin{array}{l}349 \\
298 \\
92 \\
214 \\
40 \\
28\end{array}$ & $\begin{array}{l}34.2 \% \\
29.2 \% \\
9.0 \% \\
21.0 \% \\
3.9 \% \\
2.7 \%\end{array}$ & & \\
\hline & & $\mathrm{n}$ & Mean (SD) & $\mathrm{n}$ & Mean (SD) \\
\hline $\begin{array}{l}\text { Age } \\
\text { Weight }\end{array}$ & & $\begin{array}{l}1021 \\
980\end{array}$ & $\begin{array}{l}59(10.2) \\
68.7(14.1)\end{array}$ & $\begin{array}{l}1063 \\
1058\end{array}$ & $\begin{array}{l}56.3(12.9) \\
75.2(16.6)\end{array}$ \\
\hline
\end{tabular}

BMI: body mass index; DM: diabetes mellitus; HNC: head and neck cancer. 
Table 3

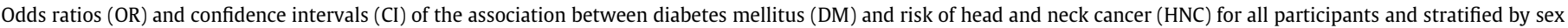
and HNC sub-site.

\begin{tabular}{|c|c|c|c|c|c|c|c|c|}
\hline & & \multicolumn{2}{|c|}{ Cases } & \multicolumn{2}{|c|}{ Controls } & \multirow[t]{2}{*}{ p-value } & \multirow[t]{2}{*}{ OR } & \multirow[t]{2}{*}{$95 \% \mathrm{CI}$} \\
\hline & & $\mathrm{n}$ & $\%$ & $\mathrm{n}$ & $\%$ & & & \\
\hline \multirow[t]{3}{*}{ All individuals ${ }^{a}$} & & $(\mathrm{n}=$ & & $(n=1$ & & & & \\
\hline & Without DM & 871 & $85.3 \%$ & 854 & $80.3 \%$ & 0.022 & 1 & \\
\hline & With DM & 150 & $14.7 \%$ & 209 & $19.7 \%$ & & 0.68 & $(0.49-0.95)$ \\
\hline \multicolumn{9}{|l|}{ By sex } \\
\hline \multirow[t]{3}{*}{ Male } & & $(\mathrm{n}=$ & & $(n=6$ & & & & \\
\hline & Without DM & 758 & $85.7 \%$ & 554 & $79.9 \%$ & 0.042 & 1 & \\
\hline & With DM & 126 & $14.3 \%$ & 139 & $20.1 \%$ & & 0.68 & $(0.47-0.99)$ \\
\hline \multirow[t]{3}{*}{ Female } & & $(n=$ & & $(n=3$ & & & & \\
\hline & Without DM & 113 & $82.5 \%$ & 300 & $81.1 \%$ & 0.532 & 1 & \\
\hline & With DM & 24 & $17.5 \%$ & 70 & $18.9 \%$ & & 0.80 & $(0.39-1.63)$ \\
\hline \multicolumn{9}{|l|}{ By HNC sub-site } \\
\hline \multirow[t]{3}{*}{ Oral cavity } & & $(\mathrm{n}=$ & & $(n=1$ & & & & \\
\hline & Without DM & 288 & $82.5 \%$ & 854 & $80.3 \%$ & 0.221 & 1 & \\
\hline & With DM & 61 & $17.5 \%$ & 209 & $19.7 \%$ & & 0.75 & $(0.48-1.19)$ \\
\hline \multicolumn{2}{|c|}{ Pharynx (oropharynx + hypopharynx) } & $(\mathrm{n}=$ & & $(\mathrm{n}=1$ & & & & \\
\hline & Without DM & 345 & $88.5 \%$ & 854 & $80.3 \%$ & $<0.001$ & 1 & \\
\hline & With DM & 45 & $11.5 \%$ & 209 & $19.7 \%$ & & 0.43 & $(0.27-0.68)$ \\
\hline \multirow[t]{3}{*}{ Larynx } & & $(\mathrm{n}=$ & & $(\mathrm{n}=1$ & & & & \\
\hline & Without DM & 175 & $81.8 \%$ & 854 & $80.3 \%$ & 0.465 & 1 & \\
\hline & With DM & 39 & $18.2 \%$ & 209 & $19.7 \%$ & & 0.83 & $(0.51-1.37)$ \\
\hline
\end{tabular}

a OR adjusted for age, sex, body mass index, tobacco, alcohol and centre.

b OR adjusted for age, body mass index, tobacco, alcohol and centre.

among current smokers ( $\mathrm{OR}=0.13 ; 95 \% \mathrm{CI}: 0.04-0.44)$ and heavy drinkers (OR $=0.31 ; 95 \% \mathrm{CI}: 0.11-0.88)$ (Table 6).

Although there is no sufficient statistical power to perform separate analysis for oropharyngeal and hypopharyngeal cancer, an exploratory analysis indicated a lower risk of hypopharyngeal cancer in diabetic metformin users. The risk of oropharyngeal cancer was decreased in both metformin users and non-users (data not shown).

\section{Discussion}

In this case-control study was found an inverse association between DM and HNC. This association was also observed in subgroups such as men, current smokers, heavy drinkers, and participants with pharyngeal and laryngeal cancer. A possible explanation for this decreased risk could be metformin use in participants with DM. Indeed, metformin users in our study had the lowest risk of HNC, and a decreased risk of HNC was also observed in metformin users who were current smokers or heavy drinkers.

This study has several strengths, including the availability of A1C results for most participants. Indeed, if authors had used self-reported information only, as has been done in other studies, a considerable percentage of cases (30.5\%) and controls (28\%) would have been wrongly classified as not having DM, and the observed association between DM and HNC would have been biased. However, the study also has limitations. Controls who were visitors in cancer hospitals were excluded from metformin analyses, since they did not have medical records in which were possible verify metformin use. Moreover, as in other studies, we were unable to separate DM by type (Type 1 or Type 2), as this information was missing for $33.3 \%$ of cases and $25.8 \%$ of controls. Although metformin is mostly used in Type $2 \mathrm{DM}$, metformin use in individuals with Type $1 \mathrm{DM}$ has increased in recent years, as it may lead to contribute to a decrease in the daily dose of insulin [26]. In present study, metformin was used by five $(27.8 \%)$ of the 18 participants with Type $1 \mathrm{DM}$. Although it is important, as in the most studies evaluating the association between metformin, DM and cancer, the present study could not be adjusted for dosage or duration of metformin use since this information was present only for $5 \%$ of DM individuals.

Previous studies on the association between DM and HNC subsites have shown contradictory results [9,10,13-16,27]. Findings in the current study were similar to those from the SEER database for people over 68 years old $(\mathrm{OR}=0.92 ; 95 \% \mathrm{CI}$ : 0.88-0.96) [16] and those of a study on men ( $\mathrm{OR}=0.85$ for cancer of the oral cavity + pharyngeal cancer, $95 \% \mathrm{CI}$ : $0.82-0.89$; $\mathrm{OR}=0.76$ for laryngeal cancer, 95\% CI: 0.71-0.80) [9]. In agreement with current study, some previous studies have reported a decreased cancer risk among metformin users. However, the protective effect of metformin use on HNC is not conclusive [21,22]. Sikka et al. [28] demonstrated that metformin may inhibit cell growth in squamous cell carcinoma of the head and neck. Thus the protection conferred by metformin use may be explained by its role in the activation of adenosine monophosphate-activated protein kinase (AMPK) [19,29]. AMPK is an enzyme and its activation inhibits protein synthesis and the action of the mTOR protein. mTOR is important for cell growth and its activity is deregulated in various cancers [19,30]. The mTOR pathway is regulated by both AMPK and AKT, which have opposite functions. In response to an external stimulus, AKT activates the mTOR pathway, contributing to cell proliferation. On the other hand, the AMPK can reduce the action of mTOR. Metformin use may activate AMPK, thus inhibiting mTOR action and decreasing cell proliferation $[11,19,31]$.

Persistent activation of AKT is present in various cancers, including HNC [32]. Although tobacco and alcohol consumption are the main risk factors for HNC, the molecular mechanism involved is not clear and few studies have investigated the association between these risk factors and AKT and mTOR activation, especially in HNC. One study showed that alcohol and tobacco activate AKT [33]. Another study showed that NKK, a main tobacco carcinogen, is associated with activation of AKT in HNC patients [34]. Likewise, tobacco promotes lung tumorigenesis through activation of signalling the AKT/mTOR pathway [35].

Present results indicated that DM was inversely associated with HNC in current smokers and heavy smokers, though this inverse association was restricted to metformin users. The present study 
Table 4

Odds ratios (OR) and confidence intervals (CI) of head and neck cancer (HNC) according to diabetes mellitus (DM) by level of tobacco and alcohol consumption.

\begin{tabular}{|c|c|c|c|c|c|c|c|c|}
\hline & & \multicolumn{2}{|c|}{ Cases } & \multicolumn{2}{|c|}{ Controls } & \multirow[t]{2}{*}{ p-value } & \multirow[t]{2}{*}{$\mathrm{OR}^{\mathrm{a}}$} & \multirow[t]{2}{*}{$95 \% \mathrm{CI}$} \\
\hline & & $\mathrm{n}$ & $\%$ & $\mathrm{n}$ & $\%$ & & & \\
\hline \multicolumn{9}{|l|}{ Smoking status ${ }^{\mathrm{a}}$} \\
\hline \multirow[t]{3}{*}{ Non-smoker } & & $(\mathrm{n}=$ & & $(n=5$ & & & & \\
\hline & Without DM & 62 & $82.7 \%$ & 433 & $82.5 \%$ & 0.926 & 1 & \\
\hline & With DM & 13 & $17.3 \%$ & 92 & $17.5 \%$ & & 1.04 & $(0.50-2.16)$ \\
\hline \multirow[t]{3}{*}{ Former smoker } & & $(\mathrm{n}=$ & & $(n=3$ & & & & \\
\hline & Without DM & 187 & $75.1 \%$ & 272 & $75.6 \%$ & 0.966 & 1 & \\
\hline & With DM & 62 & $24.9 \%$ & 88 & $24.4 \%$ & & 1.01 & $(0.63-1.62)$ \\
\hline \multirow[t]{3}{*}{ Current smoker } & & $(\mathrm{n}=$ & & $(\mathrm{n}=1$ & & & & \\
\hline & Without DM & 619 & $89.7 \%$ & 145 & $84.3 \%$ & 0.003 & 1 & \\
\hline & With DM & 71 & $10.3 \%$ & 27 & $15.7 \%$ & & 0.42 & $(0.24-0.74)$ \\
\hline \multicolumn{9}{|l|}{ Drinking status ${ }^{\mathrm{b}}$} \\
\hline \multirow{3}{*}{ Non-drinker } & & $(\mathrm{n}=$ & & $(n=3$ & & & & \\
\hline & Without DM & 70 & $83.3 \%$ & 278 & $78.8 \%$ & 0.086 & 1 & \\
\hline & With DM & 14 & $16.7 \%$ & 75 & $21.2 \%$ & & 0.47 & $(0.20-1.11)$ \\
\hline \multirow[t]{3}{*}{ Former drinker } & & $(\mathrm{n}=$ & & $(n=2$ & & & & \\
\hline & Without DM & 309 & $84.2 \%$ & 185 & $78.4 \%$ & 0.927 & 1 & \\
\hline & With DM & 58 & $15.8 \%$ & 51 & $21.6 \%$ & & 1.03 & $(0.58-1.82)$ \\
\hline \multirow[t]{3}{*}{ Current drinker } & & $(\mathrm{n}=$ & & $(\mathrm{n}=4$ & & & & \\
\hline & Without DM & 448 & $86.2 \%$ & 374 & $82.4 \%$ & 0.159 & 1 & \\
\hline & With DM & 72 & $13.8 \%$ & 80 & $17.6 \%$ & & 0.71 & $(0.45-1.14)$ \\
\hline \multicolumn{9}{|c|}{ Tobacco consumption (in pack-years) } \\
\hline \multirow[t]{3}{*}{ Non-smoker } & & $(\mathrm{n}=$ & & $(n=5$ & & & & \\
\hline & Without DM & 62 & $82.7 \%$ & 433 & $82.5 \%$ & 0.926 & 1 & \\
\hline & With DM & 13 & $17.3 \%$ & 92 & $17.5 \%$ & & 1.04 & $(0.50-2.16)$ \\
\hline \multirow[t]{3}{*}{$0-40$} & & $(\mathrm{n}=$ & & $(n=3$ & & & & \\
\hline & Without DM & 303 & $86.3 \%$ & 306 & $80.1 \%$ & 0.400 & 1 & \\
\hline & With DM & 48 & $13.7 \%$ & 76 & $19.9 \%$ & & 0.81 & $(0.50-1.32)$ \\
\hline \multirow[t]{3}{*}{$>40$} & & $(\mathrm{n}=$ & & $(\mathrm{n}=1$ & & & & \\
\hline & Without DM & 503 & $85.5 \%$ & 111 & $74.0 \%$ & 0.002 & 1 & \\
\hline & With DM & 85 & $14.5 \%$ & 39 & $26.0 \%$ & & 0.44 & $(0.26-0.74)$ \\
\hline \multicolumn{9}{|c|}{ Alcohol consumption (in $\mathrm{g} /$ day) ${ }^{\mathrm{b}}$} \\
\hline \multirow[t]{3}{*}{ Non-drinker } & & $(\mathrm{n}=$ & & $(n=3$ & & & & \\
\hline & Without DM & 70 & $83.3 \%$ & 278 & $78.8 \%$ & 0.086 & 1 & \\
\hline & With DM & 14 & $16.7 \%$ & 75 & $21.2 \%$ & & 0.47 & $(0.20-1.11)$ \\
\hline \multirow[t]{3}{*}{$0-40$} & & $(\mathrm{n}=$ & & $(n=5$ & & & & \\
\hline & Without DM & 194 & $82.2 \%$ & 427 & $82.1 \%$ & 0.775 & 1 & \\
\hline & With DM & 42 & $17.8 \%$ & 93 & $17.9 \%$ & & 0.93 & $(0.55-1.57)$ \\
\hline \multirow[t]{3}{*}{$>40$} & & $(\mathrm{n}=$ & & $(\mathrm{n}=1$ & & & & \\
\hline & Without DM & 563 & $86.5 \%$ & 132 & $77.6 \%$ & 0.027 & 1 & \\
\hline & With DM & 88 & $13.5 \%$ & 38 & $22.4 \%$ & & 0.56 & $(0.33-0.94)$ \\
\hline
\end{tabular}

${ }^{\text {a }}$ OR adjusted for age, sex, body mass index, alcohol and centre.

b OR adjusted for age, sex, body mass index, tobacco and centre.

is the first to report a lower risk of HNC among diabetic metformin users who were heavy smokers. Metformin use has been reported to prevent tobacco carcinogen-induced lung tumorigenesis in animal models [36]. Indeed, metformin has been suggested as a chemopreventive agent against lung cancer among heavy smokers [37]. The mechanism of metformin may be similar in HNC and lung cancer, since the main risk factor for both is tobacco smoke.

Our study is the first to investigate the association between metformin use and HNC in diabetic individuals who are heavy drinkers. A decreased risk of HNC is not entirely surprising considering the literature on animal models. In one study, a group of rats with chronic ethanol consumption showed a reduction in AMPK enzyme, but the group with ethanol consumption and treated with metformin showed improvement in hepatic injury through activation of AMPK. The AMPK level was similar in rats without metformin and without alcohol consumption [38]. Among heavy alcohol drinkers, the protective effect for HNC observed in diabetic metformin users might be explained by activation of AMPK by metformin, but further studies should carried out to evaluate and understand this mechanism.

We observed an inverse association between HNC and DM in all metformin users, but the associations were only statistically significant for laryngeal cancer. Becker et al. [22] also reported a reduction in the risk of laryngeal cancer in long-term metformin users. Results also showed an inverse association between pharyngeal cancer and DM, regardless of metformin use. Despite the lack of statistical power to study oropharyngeal and hypopharyngeal cancer separately, the results indicated a reduced risk of hypopharygeal cancer among diabetic metformin users. All diabetic participants had a reduced risk of oropharyngeal cancer regardless of metformin use. In a pooled analysis, no association was found between DM and cancer of the oropharynx or other HNC subsites [27]. It is noteworthy that pharyngeal cancers are different from laryngeal cancers in pathogenesis and prognosis [3,39], which can explain differences in results. Although the incidence of both oropharyngeal and laryngeal cancer are higher in men, there is a 
Table 5

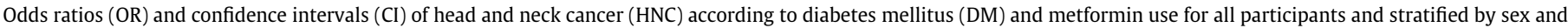
HNC sub-site.

\begin{tabular}{|c|c|c|c|c|c|c|c|c|}
\hline & & \multicolumn{2}{|l|}{ Cases } & \multicolumn{2}{|l|}{ Controls } & \multirow[t]{2}{*}{ p-value } & \multirow[t]{2}{*}{ OR } & \multirow[t]{2}{*}{$95 \% \mathrm{CI}$} \\
\hline & & $\mathrm{n}$ & $\%$ & $\mathrm{n}$ & $\%$ & & & \\
\hline \multirow[t]{4}{*}{ All individuals ${ }^{\mathrm{a}}$} & & $(\mathrm{n}=1021)$ & & $(n=587)$ & & & & \\
\hline & Without DM & 871 & $85.3 \%$ & 470 & $80.1 \%$ & 0.067 & 1 & \\
\hline & DM and metformin & 40 & $3.9 \%$ & 48 & $8.2 \%$ & 0.049 & 0.54 & $(0.29-0.99)$ \\
\hline & DM without metformin & 110 & $10.8 \%$ & 69 & $11.8 \%$ & 0.142 & 0.72 & $(0.46-1.12)$ \\
\hline \multicolumn{9}{|l|}{ By sex ${ }^{\mathrm{b}}$} \\
\hline \multirow[t]{4}{*}{ Male } & & $(\mathrm{n}=885)$ & & $(n=322)$ & & & & \\
\hline & Without DM & 758 & $85.7 \%$ & 257 & $79.8 \%$ & 0.089 & 1 & \\
\hline & DM and metformin & 33 & $3.7 \%$ & 25 & $7.8 \%$ & 0.073 & 0.51 & $(0.24-1.07)$ \\
\hline & DM without metformin & 93 & $10.5 \%$ & 40 & $12.4 \%$ & 0.134 & 0.67 & $(0.39-1.13)$ \\
\hline \multirow[t]{4}{*}{ Female } & & $(\mathrm{n}=137)$ & & $(n=265)$ & & & & \\
\hline & Without DM & 113 & $82.5 \%$ & 213 & $80.4 \%$ & 0.828 & 1 & \\
\hline & DM and metformin & 7 & $5.1 \%$ & 23 & $8.7 \%$ & 0.577 & 0.74 & $(0.26-2.11)$ \\
\hline & DM without metformin & 17 & $12.4 \%$ & 29 & $10.9 \%$ & 0.744 & 0.88 & $(0.40-1.91)$ \\
\hline \multicolumn{9}{|l|}{ HNC sub-site ${ }^{a}$} \\
\hline \multirow[t]{4}{*}{ Oral cavity } & & $(\mathrm{n}=349)$ & & $(n=587)$ & & & & \\
\hline & Without DM & 288 & $82.5 \%$ & 470 & $80.1 \%$ & 0.429 & 1 & \\
\hline & DM and metformin & 22 & $6.3 \%$ & 48 & $8.2 \%$ & 0.365 & 0.72 & $(0.36-1.46)$ \\
\hline & DM without metformin & 39 & $11.2 \%$ & 69 & $11.8 \%$ & 0.293 & 0.74 & $(0.42-1.30)$ \\
\hline \multirow[t]{4}{*}{ Pharynx (oropharynx + hypopharynx) } & & $(n=390)$ & & $(n=587)$ & & & & \\
\hline & Without DM & 345 & $88.5 \%$ & 470 & $80.1 \%$ & 0.002 & 1 & \\
\hline & DM and metformin & 11 & $2.8 \%$ & 48 & $8.2 \%$ & 0.023 & 0.34 & $(0.13-0.86)$ \\
\hline & DM without metformin & 34 & $8.7 \%$ & 69 & $11.8 \%$ & 0.004 & 0.41 & $(0.22-0.75)$ \\
\hline \multirow[t]{4}{*}{ Larynx } & & $(n=214)$ & & $(n=587)$ & & & & \\
\hline & Without DM & 175 & $81.8 \%$ & 470 & $80.1 \%$ & 0.049 & 1 & \\
\hline & DM and metformin & 7 & $3.3 \%$ & 48 & $8.2 \%$ & 0.019 & 0.28 & $(0.10-0.81)$ \\
\hline & DM without metformin & 32 & $15.0 \%$ & 69 & $11.8 \%$ & 0.655 & 1.16 & $(0.60-2.26)$ \\
\hline
\end{tabular}

a OR adjusted for age, sex, body mass index, tobacco and alcohol.

b OR adjusted for age, body mass index, tobacco and alcohol.

Table 6

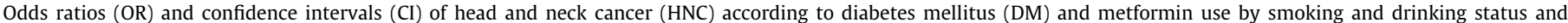
consumption level of tobacco and alcohol.

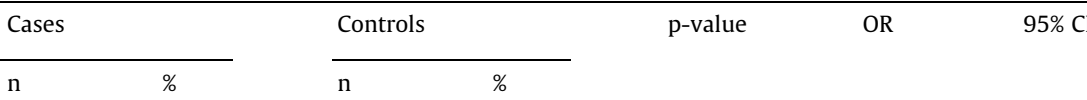

Smoking status

Non smoker

Without DM

$\mathrm{DM}$ and metformin

DM without metformin

Former smoker

Without DM

DM and metformin

DM without metformin

Current smoker

Without DM

$\mathrm{DM}$ and metformin

DM without metformin

Drinking status Non drinker

Former drinker

ithout DM

$\mathrm{DM}$ and metformin DM without metformin

Without DM

$\mathrm{DM}$ and metformin

DM without metformin

Current drinker

Without DM

$\mathrm{DM}$ and metformin

DM without metformin

$\begin{array}{ll}(\mathrm{n}=75) & \\ 62 & 82.7 \% \\ 6 & 8.0 \% \\ 7 & 9.3 \% \\ (\mathrm{n}=249) & \\ 187 & 75.1 \% \\ 20 & 8.0 \% \\ 42 & 16.9 \% \\ (\mathrm{n}=690) & \\ 619 & 89.7 \% \\ 13 & 1.9 \% \\ 58 & 8.4 \%\end{array}$

$(\mathrm{n}=307)$

$246-80.1 \%$

$29 \quad 9.4 \%$

32

$9.4 \%$

0.421

$(\mathrm{n}=178)$

138

$14 \quad 7.9 \%$

$26 \quad 14.6 \%$

$14.6 \%$

( $\mathrm{n}=197)$

$83 \quad 85.6 \%$

$5 \quad 5.2 \%$

$5.2 \%$
$9.3 \%$

$(\mathrm{n}=84)$

70

5

9

$(\mathrm{n}=367)$

309

14

44

( $\mathrm{n}=520)$

448

21

51
$8.4 \%$

$\mathrm{n}=238)$

185

$83.3 \%$

$6.0 \%$

$10.7 \%$

25

28

( $\mathrm{n}=143$ )

112

$84.2 \%$

$3.8 \%$

11

20

( $\mathrm{n}=189$ )

159

$86.2 \%$

$4.0 \%$

$9.8 \%$
12

18

\section{$77.7 \%$}

$10.5 \%$

$11.8 \%$

$78.3 \%$

$7.7 \%$

$14.0 \%$

$84.1 \%$

$6.3 \%$

$9.5 \%$
0.250

1

0.68

0.57

1

0.92

1.13

0.71

1

0.13

0.61

0.001

0.269

0.118

0.274

0.061

0.53

0.39

0.818

0.541

0.934

1

0.72

1.03

0.841

0.572

0.818
1

0.74

0.91
$(0.04-0.44)$

$(0.17-1.66)$
$(0.15-1.05)$

(0.26-2.05)

(0.49-2.19)

(0.25-1.83)

(0.22-1.49)

(0.40-2.14)

(0.59-2.15)

(0.26-1.46)

(0.27-2.08)

(0.41-2.02) 
Table 6 (continued)

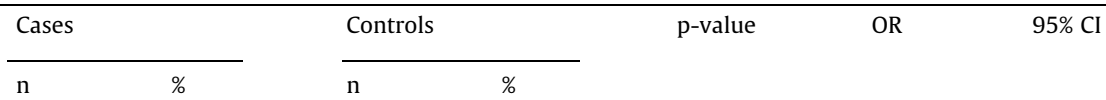

Tobacco consumption (in pack-years)

Non-smoker

Without DM
DM and metformin
DM without metformin

$0-40$

$>40$

DM without metformin

Without DM

DM and metformin

DM without metformin

Without DM

DM and metformin

DM without metformin

Alcohol consumption (in g/day)

Non-drinker

Without DM

DM and metformin

DM without metformin

$0-40$

Without DM

DM and metformin

DM without metformin

$>40$

Without DM

DM and metformin

DM without metformin

$\begin{array}{ll}(\mathrm{n}=75) & \\ 62 & 82.7 \% \\ 6 & 8.0 \% \\ 7 & 9.3 \% \\ (\mathrm{n}=351) & \\ 303 & 86.3 \% \\ 13 & 3.7 \% \\ 35 & 10.0 \% \\ (\mathrm{n}=588) & \\ 503 & 85.5 \% \\ 20 & 3.4 \% \\ 65 & 11.1 \%\end{array}$

( $\mathrm{n}=84$

70

5

$\mathrm{n}=236$

194

15

27

$(\mathrm{n}=651)$

563

20

68

$10.7 \%$

$6.4 \%$

$11.4 \%$

$3.1 \%$

$10.4 \%$

$\begin{array}{lllll}(\mathrm{n}=307) & & & & \\ 246 & 80.1 \% & 0.421 & 1 & \\ 29 & 9.4 \% & 0.443 & 0.68 & (0.25-1.83) \\ 32 & 10.4 \% & 0.250 & 0.57 & (0.22-1.49) \\ (\mathrm{n}=209) & & & & \\ 172 & 82.3 \% & 0.164 & 1 & \\ 13 & 6.2 \% & 0.065 & 0.42 & (0.17-1.06) \\ 24 & 11.5 \% & 0.816 & 1.08 & (0.56-2.10) \\ (\mathrm{n}=66) & & & & \\ 49 & 74.2 \% & 0.718 & 1 & \\ 6 & 9.1 \% & 0.066 & 0.36 & (0.12-1.07) \\ 11 & 16.7 \% & 0.104 & 0.53 & (0.25-1.14)\end{array}$

$(\mathrm{n}=238)$

$11.8 \%$

0.118

0.274

1

0.53

(0.17-1.66)

( $\mathrm{n}=248$ )

$(\mathrm{n}=248$
203

16

29

0.061

0.39

(0.15-1.05)

( $\mathrm{n}=84)$

$(\mathrm{n}=84)$
68

7
$81.9 \%$

$6.5 \%$

\section{$11.7 \%$}

0.924

0.704

0.958

1.21

0.98

(0.46-3.16)

(0.48-2.00)

$81.0 \% \quad 0.036 \quad 1$

$8.3 \%-0.028-0.31$

$\begin{array}{lll}10.7 \% & 0.571 & 0.78\end{array}$
1

\footnotetext{
a OR adjusted for age, sex, body mass index and alcohol.

${ }^{b}$ OR adjusted for age, sex, body mass index and tobacco.
}

slightly higher incidence in oropharyngeal cancer among women in some European countries $[2,39,40]$. Unlike the laryngeal cancer, an increase in oropharyngeal incidence has occurred in whites and younger individuals [39]. There is growing evidence that a substantial proportion of oropharyngeal cancers are associated with human papillomavirus (HPV) infection [39,40]. Unfortunately, there was no information on HPV in our study; therefore this information was not added in the models, which could have caused some bias in the results for oropharyngeal cancer.

\section{Conclusion}

We found an inverse association between DM and HNC. The protective effect of DM was at least partially explained by metformin use, since metformin users had an even lower risk of HNC. The inverse association of HNC risk among metformin users was stronger in current smokers and heavy drinkers.

\section{Conflict of interest}

None declared.

\section{Acknowledgements}

The authors would like to thank the members of the GENCAPO (Brazilian Head and Neck Genome Project) and São Paulo Research Foundation (FAPESP). The study was supported by FAPESP (grant 2010/51168-0, 2013/20548-0, 2013/21702-3 and 2014/18893-4).

\section{References}

[1] Pezzuto F, Buonaguro L, Caponigro F, Ionna F, Starita N, Annunziata C, et al. Update on head and neck cancer: current knowledge on epidemiology, risk factors, molecular features and novel therapies. Oncology 2015;89:125-36. http://dx.doi.org/10.1159/000381717.
[2] Ferlay J, Soerjomataram I, Dikshit R, Eser S, Mathers C, Rebelo M, et al. Cancer incidence and mortality worldwide: sources, methods and major patterns in GLOBOCAN 2012. Int J Cancer 2015;136:359-86. http://dx.doi.org/10.1002/ iic.29210.

[3] Gao J, Panizza B, Johnson NW, Coman S, Clough AR. Basic consideration of research strategies for head and neck cancer. Front Med 2012;6:339-53. http://dx.doi.org/10.1007/s11684-012-0213-7.

[4] Hashibe M, Brennan P, Chuang SC, Boccia S, Castellsague X, Chen C, et al. Interaction between tobacco and alcohol use and the risk of head and neck cancer: pooled analysis in the International Head and Neck Cancer Epidemiology Consortium. Cancer Epidemiol Biomarkers Prev 2009;18:541-50. http://dx.doi.org/10.1158/1055-9965.EPI-08-0347.

[5] Ahrens W, Pohlabeln H, Foraita R, Nelis M, Lagiou P, Lagiou A, et al. Oral health, dental care and mouthwash associated with upper aerodigestive tract cancer risk in Europe: the ARCAGE study. Oral Oncol 2014;50:616-25. http://dx.doi. org/10.1016/i.oraloncology.2014.03.001.

[6] Conway DI, Brenner DR, Mcmahon AD, Macpherson LMD, Agudo A, Ahrens W, et al. Estimating and explaining the effect of education and income on head and neck cancer risk: INHANCE consortium pooled analysis of 31 case-control studies from 27 countries. Int J Cancer 2015;136:1125-39. http://dx.doi.org/ $10.1002 /$ ijc. 29063.

[7] Delahaye-Sourdeix M, Oliver J, Timofeeva MN, Gaborieau V, Johansson M, Chabrier A, et al. The 12p13.33/RAD52 locus and genetic susceptibility to squamous cell cancers of upper aerodigestive tract. PLoS ONE 2015;10:1-12. http://dx.doi.org/10.1371/journal.pone.0117639.

[8] Lubin JH, Gaudet MM, Olshan AF, Kelsey K, Boffetta P, Brennan P, et al. Body mass index, cigarette smoking, and alcohol consumption and cancers of the oral cavity, pharynx, and larynx: modeling odds ratios in pooled case-control data. Am J Epidemiol 2010;171:1250-61. http://dx.doi.org/10.1093/aje/ kwq088.

[9] Atchison EA, Gridley G, Carreon JD, Leitzmann MF, McGlynn KA. Risk of cancer in a large cohort of U.S. veterans with diabetes. Int J Cancer 2011;128:635-43. http://dx.doi.org/10.1002/iic.25362.

[10] Bosetti C, Rosato V, Polesel J, Levi F, Talamini R, Montella M, et al. Diabetes mellitus and cancer risk in a network of case-control studies. Nutr Cancer 2012;64:643-51. http://dx.doi.org/10.1080/01635581.2012.676141.

[11] Vigneri P, Frasca F, Sciacca L, Pandini G, Vigneri R. Diabetes and cancer. Endocr Relat Cancer 2009;16:1103-23. http://dx.doi.org/10.1677/ERC-09-0087.

[12] Bansal D, Bhansali A, Kapil G, Krishna U, Tiwari P. Type 2 diabetes and risk of prostate cancer: a meta-analysis of observational studies. Prostate Cancer Prostatic Dis 2013;16:151-8. http://dx.doi.org/10.1038/pcan.2012.40.

[13] Kuriki K, Hirose K, Tajima K. Diabetes and cancer risk for all and specific sites among Japanese men and women. Eur J Cancer Prev 2007;16:83-9. http://dx. doi.org/10.1097/01.cei.0000228404.37858.40. 
[14] Nakamura K, Wada K, Tamai Y, Tsuji M, Kawachi T, Hori A, et al. Diabetes mellitus and risk of cancer in Takayama: a population-based prospective cohort study in Japan. Cancer Sci 2013;104:1362-7. http://dx.doi.org/ 10.1111 /cas. 12235

[15] Tseng KS, Lin C, Lin YS, Weng SF. Risk of head and neck cancer in patients with diabetes mellitus: a retrospective cohort study in Taiwan. JAMA Otolaryngol Head Neck Surg 2014;140:746-53. http://dx.doi.org/ 10.1001/jamaoto.2014.1258.

[16] Stott-Miller M, Chen C, Schwartz SM. Type II diabetes and metabolic syndrome in relation to head and neck squamous cell carcinoma risk: a SEER-Medicare database study. Cancer Epidemiol 2013;37:428-33. http://dx.doi.org/10.1016/ j.canep.2013.03.006.

[17] Giovannucci E, Harlan DM, Archer MC, Bergenstal RM, Gapstur SM, Habel LA, et al. Diabetes and cancer: a consensus report. Diabetes Care 2010;33:1674-85. http://dx.doi.org/10.2337/dc10-0666.

[18] Zhang ZJ, Zheng ZJ, Kan H, Song Y, Cui W, Zhao G, et al. Reduced risk of colorectal cancer with metformin therapy in patients with type 2 diabetes: a meta-analysis. Diabetes Care 2011;34:2323-8. http://dx.doi.org/10.2337/ dc11-0512.

[19] Noto H, Goto A, Tsujimoto T, Noda M. Cancer risk in diabetic patients treated with metformin: a systematic review and meta-analysis. PLoS ONE 2012;7:1-9. http://dx.doi.org/10.1371/journal.pone.0033411.

[20] Tseng CH. Metformin may reduce breast cancer risk in Taiwanese woman with type 2 diabetes. Breast Cancer Res Treat 2014;145:785-90. http://dx.doi.org/ 10.1007/s00592-014-0562-6.

[21] Yen YC, Lin C, Lin SW, Lin YS, Weng SF. Effect of metformin on the incidence of head and neck cancer in diabetics. Head Neck 2014;37:1268-73. http://dx.doi. org/10.1002/hed.23743.

[22] Becker C, Jick SS, Meier CR, Bodmer M. Metformin and the risk of head and neck cancer: a case-control analysis. Diabetes Obes Metab 2014;16:1148-54. http://dx.doi.org/10.1111/dom.12351.

[23] World Health Organization. International Statistical Classification of Diseases and Related Health Problems. 10th Revision. 2nd ed; 2005.

[24] Hashibe M, Brennan P, Benhamou S, Castellsague X, Chen C, Curado MP, et al. Alcohol drinking in never users of tobacco, cigarette smoking in never drinkers, and the risk of head and neck cancer: pooled analysis in the international head and neck cancer epidemiology consortium. J Natl Cancer Inst 2007;99:777-89. http://dx.doi.org/10.1093/inci/djk179.

[25] American Diabetes Association. Diagnosis and classification of diabetes mellitus. Diabetes Care 2014;37:81-90. http://dx.doi.org/10.2337/dc14-S081.

[26] Liu C, Wu D, Zheng X, Li P, Li L. Efficacy and safety of metformin for patients with type 1 diabetes mellitus: a meta-analysis. Diabetes Technol Ther 2015;17:142-8. http://dx.doi.org/10.1089/dia.2014.0190.

[27] Stott-Miller M, Chen C, Chuang SC, Lee YC, Boccia S, Brenner H, et al. History of diabetes and risk of head and neck cancer: a pooled analysis from the international head and neck cancer epidemiology consortium. Cancer
Epidemiol Biomarkers Prev 2012;21:294-304. http://dx.doi.org/10.1158 1055-9965.EPI-11-0590.

[28] Sikka a, Kaur M, Agarwal C, Deep G, Agarwal R. Metformin suppresses growth of human head and neck squamous cell carcinoma via global inhibition of protein translation. Cell Cycle 2012;11:1374-82. http://dx.doi.org/10.4161/ cc.19798.

[29] Musi N, Hirshman MF, Nygren J, Svanfeldt M, Bavenholm P, Rooyackers O, et al Metformin increases AMP-activated protein kinase activity in skeletal muscle of subjects with type 2 diabetes. Diabetes 2002;51:2074-81.

[30] Del Barco S, Vazquez-Martin A, Cufí S, Oliveras-Ferraros C, Bosch-Barrera J Joven J, et al. Metformin: multi-faceted protection against cancer. Oncotarget 2011;2:896-917.

[31] Bhat A, Sebastiani G, Bhat M. Systematic review: preventive and therapeutic applications of metformin in liver disease. World J Hepatol 2015;7:1652-9. http://dx.doi.org/10.4254/wih.v7.i12.1652.

[32] Amornphimoltham P, Sriuranpong V, Patel V, Benavides F, Conti CJ, Sauk J, et al. Persistent activation of the Akt pathway in head and neck squamous cell carcinoma: a potential target for UCN-01. Clin Cancer Res 2004;10:4029-37. http://dx.doi.org/10.1158/1078-0432.CCR-03-0249.

[33] Islam MR, Ellis IR, Macluskey M, Cochrane L, Jones SJ. Activation of Akt at T308 and S473 in alcohol, tobacco and HPV-induced HNSCC: is there evidence to support a prognostic or diagnostic role? Exp Hematol Oncol 2014;3:1-9. http://dx.doi.org/10.1186/2162-3619-3-25.

[34] Weber SM, Bornstein S, Li Y, Malkoski SP, Wang D, Rustgi AK, et al. Tobaccospecific carcinogen nitrosamine 4-(methylnitrosamino)-1-(3-pyridyl)-1butanone induces AKT activation in head and neck epithelia. Int J Oncol 2011;39:1193-8. http://dx.doi.org/10.3892/ijo.2011.1149.

[35] Memmott RM, Dennis PA. The role of the Akt/mTOR pathway in tobacco carcinogen-induced lung tumorigenesis. Clin Cancer Res 2010;16:4-10. http:| dx.doi.org/10.1158/1078-0432.CCR-09-0234.

[36] Memmott RM, Mercado JR, Maier CR, Kawabata S, Fox SD, Dennis PA Metformin prevents tobacco carcinogen-induced lung tumorigenesis. Cancer Prev Res 2010;3:1066-76. http://dx.doi.org/10.1158/1940-6207.CAPR-10$\underline{0055}$.

[37] Antonoff MB, D'Cunha J. Teaching an old drug new tricks: metformin as a targeted therapy for lung cancer. Semin Thorac Cardiovasc Surg 2010;22:195-6. http://dx. doi.org/10.1053/i.semtcvs.2010.10.015.

[38] Zhu Z, Jiang Z, Zhou J, Zhou D, Wang W, Zhao C, et al. Involvement of insulin resistance in the protective effect of metformin against alcoholic liver injury. Alcohol Clin Exp Res 2014;38:1510-9. http://dx.doi.org/10.1111/acer.12418.

[39] Rettig EM, D’Souza G. Epidemiology of head and neck cancer. Surg Oncol Clin N Am 2015;24:379-96. http://dx.doi.org/10.1016/j.soc.2015.03.001.

[40] Simard EP, Torre LA, Jemal A. International trends in head and neck cancer incidence rates: differences by country, sex and anatomic site. Oral Oncol 2014;50:387-403. http://dx.doi.org/10.1016/i.oraloncology.2014.01.016. 